\title{
Decentralization, Horizontal Inequalities and Conflict Management in Indonesia
}

\author{
Rachael Diprose
}

This is a pre-print version of the article submitted to Ethnopolitics.

Please cite: Diprose, R. 2009. Decentralization, Horizontal Inequalities and Conflict Management in Indonesia. Ethnopolitics, 8:1, 107-134.

\begin{abstract}
The impact of decentralization on conflict dynamics is as important as its impact on service delivery and growth, as violent conflict can undo development gains. This paper argues that the impact of decentralization has been two fold. It has relieved centreperiphery tensions around longstanding grievances towards nationalist agendas in Indonesia. The evidence suggests, through examining the case of conflict affected Central Sulawesi, that decentralization has also to some extent addressed long-standing intergroup tensions and horizontal inequalities at the local level, particularly where geographically concentrated ethno-religious groups have previously been marginalised from government. It has also reduced grievances by increasing local autonomy and participation in decision making through direct elections of district heads, now a hotly contested arena of local politics.

However, significant structural and institutional change can result in new tensions, particularly when poorly planned for or monitored. Decentralization has stimulated changes in population demographics in some areas in Indonesia resulting in ethnoreligious segregation through splitting of sub-national administrative units into increasing numbers of regions. Groups with previous minority status have found safe-haven as majorities, setting the scene for how future rights of access and representation play out. Tensions run high when high-stakes local elections are contested along sensitive identity lines, or when district governments are not inclusive of minorities in their regions. This is not to say that the demographic, structural, and institutional changes with decentralization will necessarily lead to violent conflict, but rather due attention should be given to ensuring appropriate conflict management mechanisms are in place.
\end{abstract}




\title{
Decentralization, Horizontal Inequalities and Conflict Management in Indonesia $^{1}$
}

\author{
Rachael Diprose
}

\section{Introduction}

With the reduction in the number of inter-state conflicts and dramatic increase in number intra-state conflicts since the twilight years of the cold war, decentralization has gained renewed attraction among scholars and in policy circles as an institutional framework in diverse societies. In fact, a recent survey suggests that since 1980 about 95 per cent of all countries have conferred powers and responsibilities to sub-national units 'with varying degrees of political, administrative and fiscal competences' (Schrottshammer and Kievelitz, 2006: 5). Even in the post-colonial context, decentralization is displacing centralization which was pursued with such vigour as a nation-building strategy. For instance, a survey of decentralization in Africa indicates that the question is no longer about the desirability of decentralization but the degree of decentralization (Ndegwa, 2002). This popularity derives from the perception that decentralization of fiscal and/or political autonomy is one response to managing the multitude of demands of diverse groups in large nation-states. This is an alternative view to the orthodox arguments of nation states pursuing aggressive decentralization strategies such as Indonesia that decentralization brings government services and decision making closer to the populace. Decentralization has the potential to deflate national level inter-group conflict for power, resources and control, particularly in nations with diverse ethno-religious groups which are regionally concentrated. It can also take the pressure off contentious centre-periphery relations, particularly when there is a history of grievances with centralised rule and forms of cultural hegemony as has been the case in Indonesia.

Comparative experiences of the countries implementing decentralization however indicate that the relationship is more complex than was earlier postulated. Decentralization has not always succeeded in resolving or preventing conflicts. For instance, secessionist movements continue to thrive in some decentralizing states, albeit in very few of the new administrative areas (Rothchild and Roeder, 2001). The varied experiences with decentralization has adverted the attention of scholars and policy makers to prospective intervening factors. Some studies have emphasized the importance of the context specificity, especially the size and concentration of minorities, and the nature of decentralized institutions and structures (Schrottshammer and Kievelitz, 2006). Others have argued that the defining ingredient to the efficacy of decentralization as a conflict resolution strategy is the presence or absence of regional political parties (Brancati, 2006). Furthermore, other scholars have been more sceptical and have indeed implicated decentralization for the outbreak of conflicts (Brubaker, 1996; Kymlicka, 1998; Snyder, 2000).

Decentralization is criticised for encouraging the promotion of ethnic, regional or communal identities that are antithetical to national identity. On the one hand, such identities often serve as the basis for unending demands for autonomy which lead to

\footnotetext{
${ }^{1}$ The author would like to thank Ukoha Ukiwo for his contributions to this paper, and Frances Stewart, Graham Brown, and the anonymous peer reviewers for their feedback.
} 
separatist and secessionist mobilizations (Hardgrave, 1994; Kymlicka, 1998; Hechter, 2000). Although, authors such as Kymlicka (1998) and Hechter (2000), who note the dangers of such unending demands, support decentralization as an appropriate means of managing diversity. It has also been argued that decentralization generate conflicts by working against the entrenchment of democratic values. This is because it may lead to the transfer of power and resources to undemocratic social forces such as chiefs (Fanthorpe, 2006; Jackson, 2007) or provide a sphere for domination of minority groups by majority groups at the locality (Horowitz, 1991; Suberu, 1994). On the other hand, it may reduce pressures from the disparate regions of some countries to destabilise central governments, particularly if there is a long history of complaints with centralised government. For example, Suberu (2006) argues Nigeria's federal structure, with its multiplicity of subfederal constituent units, promotes the decentralization and compartmentalization of ethno-religious and regional conflicts. This reduces the capacity of such conflicts to polarize or destabilize the entire federation.

Thus, apart from extraneous factors, the relationship between decentralization and conflicts depends on how it affects power relations between groups and classes at the sub-national and local levels. This paper argues, using the case of Central Sulawesi in Indonesia, that a major factor that predicts whether decentralization would ameliorate or exacerbate conflicts between groups is the extent to which decentralization addresses perceived horizontal inequalities and group domination, as well as the extent to which the decentralization process is actually implemented according to the purview with which it was 'sold' to the populace or deviates from this.

Indonesia is a country undergoing 'democratization', following the end of the authoritarian military rule in the late 1990s. It declared Independence from Dutch colonial rule in 1945 - a form of rule that itself contributed to the formation of nationstate boundaries around diverse groups and the contentious identity politics which remain today. Indonesia is a unitary state with a central administration but significant powers have been devolved to districts to such an extent that the country is said to have implemented the substance of federalism without changing the unitary system (Tirtosudarmo, 2006). The country has some 300 ethnic groups smattered across more than 10,000 islands, although approximately ten of these make up the bulk of the population with the largest, the Javanese mainly on Java island, accounting for just less than half the population. It currently has 36 provinces within its borders at various stages of economic development. The majority of the population is Muslim, although in many districts there are ethnically and religiously concentrated groups which change the nature of majority-minority ethno-religious politics within the provincial and district boundaries. This paper argues that majority-minority identity politics is one important area which decentralization has affected in terms of the potential for conflict.

Indonesia has seen an upsurge in violent communal conflict, particularly in the period following the end of authoritarian rule, though, this has followed an uneven pattern across the country and there is sub-national variation in outbreaks of violence. This is not because democracy inherently generates conflicts. On the contrary, cross-country evidence has shown that democracies are less likely to experience civil war and communal violence than authoritarian states (Hegre et al., 2001). Rather it is in democratizing countries - i.e., states in transition such as Indonesia - that social tensions are more likely to escalate into violence (Gurr, 2000; 2001). This is because democratization is often associated with changes in power relations and structures (Ake, 
2000). When democratization is implemented simultaneously with decentralization- as in Indonesia- changes in power relations at the local level brought about by decentralization have the potential to trigger ethnic and communal violence at the locality, but at the same time may alleviate tensions depending on the local context. At the same time, as this paper argues, it can alleviate centre-periphery tensions through providing local autonomy where there has been previous central dominance, and has varying impacts on relations at the centre depending on the structures, population demographics, and contested resources of a nation state.

This article explores how the decentralization experiment has fared in Indonesia in terms of local-level conflict dynamics. Evidence presented in this article demonstrates that decentralization as a strategy of accommodating diversity can both trigger and ameliorate the potential for violent conflict at the local level. The extent to which decentralization 'triggers' or 'moderates' violent local conflict is contingent on how the decentralization implementation process is carried out and how the consequent new local political, governmental, and institution-building processes are managed. This is subsequently linked to the correlation between the advertised gains of decentralization prior to its implementation and actual outcomes - are local groups satisfied with the decentralization process in terms of their perceptions of what decentralization would provide? It is also linked to how inter-group dynamics, horizontal inequalities, and new local politics are managed in the decentralised context, which is highly conditional on local, regional and the interference of national elites, their interests, grass-roots support base, and how this is mobilised to access the fruits of decentralization. Thus, this paper does not argue that decentralization is not an appropriate course for ameliorating ethno-religious or centreperiphery tensions - in Indonesia decentralization was long demanded from the populace and was potentially the only course of action for accommodating the diverse interests of its groups. Instead this paper argues that the conflict outcomes of decentralization will depend on how the process itself is carried out, and to what extent institution-building, and government policy gives due consideration to the potential conflict outcomes of its strategies and policies.

Evidence for this argument derives from a study of the decentralization of power to the district level, bi-passing the provincial level, in Poso and Donggala Districts in Central Sulawesi Province, Indonesia. Districts are the smallest units of government to which fiscal budgets are decentralised. The qualitative and quantitative evidence for these cases was collected between 2005-2007, using both survey instruments and extensive in-depth interviews. The paper reviews the history of grievances with centre-periphery relations in Indonesia and the implementation of decentralization as a response to these grievances ${ }^{2}$. It also reviews the impact of decentralization on conflict, in particular horizontal inequalities, in the case of Central Sulawesi province. In the conclusion there is some discussion of the two sides of decentralization in terms of how it can ameliorate or exacerbate conflict as a means of managing ethno-religious diversity.

\footnotetext{
${ }^{2}$ For a longer discussion of the history of grievances with centre-periphery relations and the implementation of decentralization in Indonesia, particularly Central Sulawesi province see Diprose (2008)
} 


\section{A History of Grievances and Centre-Periphery Tensions in Indonesia}

\section{Grievances around ethno-religious identity}

In 1999, following the end of the 32-year rule of Suharto's New Order administration, Indonesia embarked on an ambitious decentralization programme. Decentralization and greater regional autonomy emerged in response to demands for the vast and diverse regions of the country to self-manage as well as to bring government services closer to beneficiaries. It can also be seen as a response to the long-standing grievances existing in the regions against 54 years of centralised government administration and the remnants of colonial forms of indirect rule and privileges given to particular ethnic groups.

Struggles for regional autonomy in Indonesia did not simply stem from 'reformasi' (the reform period) following the end of Suharto's New Order regime which ruled from 1966 until 1998. Instead, contested power relations between the centre and the regions can be found as early as the 1950s in the Independence period and even in the pre-Independence complaints of ethnic privileging and indirect rule by the Dutch colonial authorities. ${ }^{3}$ The regional autonomy debate has long been entangled with the identity politics of, on the one hand, loyalties to the unified, single Indonesian identity fought for with the birth of the Independence movement, and on the other hand, the diversity of Indonesian regional identities. According to Feith (1962: 27), by 1949 there were 366 traditionally self-aware ethnic groups in Indonesia, including ten major groups with populations of over 1 million. Ethnic groups in Indonesia are predominantly identified as groups of people with a common language and places of origin. These places of origin are often the geographic regions within the archipelago (either islands, or parts of islands) where members of the ethnic groups are born or have their ancestral ties which are usually determined along patrilineal lines. Often, members of the ethnic group have the same religion (mainly Muslim), although in some regions the same ethnic group is split across two religions, mainly Christianity and Islam. Pockets of Christians and Hinddus are found throughout the archipelago. The largest groups include the Javanese (from Java island, the centre of national government and the most populated island who are predominantly Muslim), the Balinese (mainly Hindu from Bali island), the Sundanese (mainly Muslim from West Java), the Bugis (mainly Muslim, from South Sulawesi), the Madurese (mainly Muslim from Madura island), the Batak (mainly Christian from Sumatra), amongst others. The national language, Bahasa Indonesia, is a derivative of Malay, and used throughout the archipelago.

While some of these groupings unified to overthrow the Dutch and form a single 'Indonesian' identity, natural loyalties to the communal and quasi-communal groups still existed in parallel with the unified Indonesian consciousness. Some deemed ethnic group loyalties to be in competition with loyalties to the state and the national community in the 1950 s, and thus 'local 'patriotisms' and demands for self autonomy were seen as a threat to national unity (Ibid.: 29).

Demands for greater autonomy for the regions in Indonesia emerged instead from dissatisfaction with the centralised administration. Following the struggle for Independence from the Dutch in 1945, Harvey (1977: v) maintains that many hoped for social and economic improvements for the general population. Instead, there was disappointment with the minimal change achieved by the central government

\footnotetext{
${ }^{3}$ This paper is limited in that it does not discuss centre-regional power relations prior to Indonesian Independence.
} 
administration, stimulating discontent with the centralised system. In the 1950 s too, the regions outside Java - where the central government administration was based complained of economic and political marginalisation from the centre, perceiving that government policy favoured Java (Harvey, 1977:1). ${ }^{4}$ For example, many of Indonesia's exports originated from the islands outside Java whereas Java was a net importer. However, the currency exchange rate was overvalued, favouring import prices rather than export prices, thus discriminating against the exporting regions (Feith, 1962: 6-7). Similarly, the regions in the islands outside Java were dissatisfied with the appointment of central government officials, particularly from Java, to the regional government administrations, which the 'outer islands' considered as encroaching on their autonomy (Feith, 1962: 488). ${ }^{5}$

Historically, when grievances against the centre emerged, so too did regionalism and demands for greater autonomy for the regions outside Java (Feith, 1962:487).. ${ }^{6}$ Legge (1961: 231) argues that the very motto of the Republic, "Unity in Diversity" (Bhinneka Tunggal I ka), recognises the reality of the strength of regional awareness and the presence of distinct societies in the regions such as the Minangkabau (in West Sumatra) or the Batak (in northern Sumatra). Both ethnicity and economic differences between regions were significant factors in explaining local patriotism at the time (ibid). Although the discourse at the central level has often painted these local patriotisms as a source of inter-ethnic conflict and a threat to national integration, they should be seen as the mobilisation of groups dissatisfied with centralised governance. The rebellions of the 1950s synthesised such anti-central government sentiment in the regions. For example, the Permesta rebellion ${ }^{7}$ in Sulawesi was launched to oppose the increasing influence of Sukarno and the Indonesian Communist Party, as well as the strength of the ABRI (the Indonesian Armed Forces) (Harvey, 1977: 151-153).

The complaints in the regions and the emergence of this and other movements were synonymous with 'ethnic particularism' ${ }^{8}$ and 'regionalism', but the leaders of the movement were not willing to allow such sentiments to fully develop for fear of destroying the unitary state that they had originally supported (Harvey, 1977: 153). Harvey explains that the goal of the rebels was to change national policy through regionalism, not separation from the Indonesian state (Ibid.: 152). Eventually, such demands for greater self-management were accommodated through the ratification of regional autonomy laws in the 1950s: Law No.32, $1956^{10}$, and Law No. 1, 1957 ${ }^{11}$. Yet, following the end of these rebellions, the key provisions of the 1956/57 Regional Autonomy Laws were revoked in 1959, when Sukarno implemented Guided Democracy (Legge, 1961: 209).

\footnotetext{
${ }^{4}$ See also Kahin and Kahin, (1997).

${ }^{5}$ See also Legge (1961: 19).

${ }^{6}$ See also Harvey (1977: 7) and Legge, (1961:13).

${ }^{7}$ Declaration of Charter of Inclusive Struggle (Piagam Perjuangan Semesta Alam - Permesta) in Makassar, 2 March 1957 demanding provincial autonomy. Harvey, (1977: 1 and 173).

${ }^{8}$ McKahin, in Harvey, (1977 :vi).

${ }^{9}$ Ibid.; See also Harvey (1977:152-3).

${ }^{10}$ This law was concerned with the financial relations between the centre and the autonomous regions.

${ }^{11}$ This law was enacted to modify the appointment of Regional Heads. Legge viewed this as more an attempt to weaken their office and strengthen the role of the regional parliaments. Legge, (1961:52).
} 
Following the end of Sukarno's Old Order ${ }^{12}$, the New Order administration from 1966 continued to strengthen national identity and the central administration. The New Order endeavoured to solidify the imagined Indonesian identity by promoting its own role as the guardian of the state ideology: Pancasila (the five principles). ${ }^{13}$ The New Order sought ideological legitimacy through policies that continually reinforced 'stability' in Indonesia following the instability which characterised the end of the Sukarno regime (Hooker, 1995: 5 cf. Geertz, 1990: 89). ${ }^{14}$ The cornerstone of New Order policies promoting stability was development. (Hooker and Dick, 1995: 3). This was characterised by top-down decision making and very little accommodation of local diversity (Guinness, 1994: 269). Regional cultures and traditions were incorporated into national culture by officially promoting the visual and decorative aspects, but in doing so other expressions of local culture were stifled (Foulcher, 1990: 302). For example, sentiments that could be related to SARA (suku, agama, ras, antar-golongan - ethnic, religious, racial or inter-group relations) was used as an instrument to control the expression of local diversity in Indonesia (Sen and Hill, 2000:12). The central government also controlled the regions by appointing its preferred candidates to provincial and district head positions (Governor, Bupati - District Head/Regent, Walikota - Mayor). In 1970, this phenomenon referred to as 'dropping' from the centre, resulted in 20 of the nation's 26 Governors and $60 \%$ of all Bupati and Walikota coming from the armed forces (Malley, 1999: 76). Thus, the New Order's cultural and political hegemony through legislation, tight control and the use of force on occasion, further stimulated grievances in the regions towards the centralised system of government and restrictions on the expression of local culture and identity.

However, despite all manner of mechanisms to repress regional identity and even communal conflicts as they arose, there were still sporadic outbreaks of violence under the New Order. In the restive provinces of Aceh and Papua, there were struggles against central hegemony through clashes with the military. East Timor (as it was known) was under control of the Indonesian military by use of force. ${ }^{15}$ Subversive groups were considered enemies of the state, including the Free Aceh Movement (Gerakan Aceh Merdeka - GAM) in Aceh, the Free Papua Movement (Operasi Papua Merdeka-OPM), the leaders of the actions against the state in the Tanjung Priok in 1984, the Jihad Command in 1981 (Bhakti et al., 2001). Bhakti et al. argue that the coercive policies of the New Order government were based on the 'use of force' ideology embraced by the state. This ideology included the mechanisms, processes, and coercive techniques, which were collectively and structurally carried out to maintain power and control citizens (Bhakti et al., 2001: 27). The military under the New Order would hastily deal with cases of protest using coercion and violence. Discontent with such policies was one of the driving forces behind mass public action and unrest in final years of the Suharto regime. The political, economic and fiscal crises in 1997 undermined the strength of the Suharto

\footnotetext{
12 The economic decline and chaotic politics of the Old Order culminated in its demise and massive discontent with the regime. An 'attempted coup' which saw blame attributed to the communist party triggered the take over of government by the military under Suharto. This was followed by both community and state-perpetrated violence resulting in the deaths of hundreds of thousands of Indonesians, particularly those with links to the communist party (and those labelled as communist sympathisers).

${ }^{13}$ The five principles of the Republic of Indonesia acknowledge commitment to belief in one God, a just and civilised humanity, national unity, and people's rule through consultation and representation, to achieve social justice for all Indonesians. See Guinness, Patrick (1994: 271).

${ }^{14}$ See also Hooker and Dick, (1995: 2).

${ }^{15}$ For and indepth discussion of this see Said (2001) and Samego et al. (1998).
} 
regime and led to eventual resignation of the President in May 1998. Following this, Indonesia entered a period of massive change.

\section{Decentralization in Indonesia: Responding to past grievances?}

Following the end of the New Order, the new policy of decentralization in Indonesia was first outlined in the Regional Autonomy Laws: Law No. 22, 1999 concerning 'Local Government' ${ }^{\prime 6}$ and Law No. 25, 1999 concerning 'The Fiscal Balance Between the Central Government and the Regions'. Beginning in January 2001, these laws devolved certain powers and responsibilities to district and municipal governments (kabupaten/kota) rather than the provincial governments, establishing a far more decentralised system than the de-concentrated ${ }^{17}$ and co-administrated ${ }^{18}$ systems of the past, which is evident in Figure 1 below. These laws did not only facilitate fiscal decentralization, but also greater legislation and policy making powers to the districts thus allowing for the decentralization of political power and autonomy. In all government administrative sectors Law No. 22, 1999 has devolved central government functions to regional governments (mainly district), with the exception of security and defence, foreign policy, monetary and fiscal matters, justice, and religious affairs. Provinces have a dual status as autonomous regions themselves and also as representatives of the central government in regions. As autonomous regions, provinces have the authority to manage certain matters that cross inter-district and inter municipal administration and authorities that are not implemented by the districts and municipalities. The power of districts and municipalities cover all sectors of administrative authority other than those of the central government and the provinces, including public works, health, education and culture, agriculture, transportation, industry and trade, investment, environment, land affairs, cooperatives, and manpower.

Figure 1: Changes from the deconcentrated and co-administered system of centralized governance in Indonesia to decentralization to the district level for decision making, fund raising, and some legislative powers, Law No. 22, 1999.

\footnotetext{
${ }^{16}$ Law No. 22, 1999 devolves central government powers and responsibilities to local governments in all government administrative sectors except for security and defense, foreign policy, monetary and fiscal matters, justice, and religious affairs, without conditions and limitations. It also transfers functions, personnel and assets from the central government to the provincial, as well as the district and the municipal governments (Usman, 2001: ii).

${ }^{17}$ Deconcentration is the delegation of authority by the central government to the governor of a province and/or a central government official in the province.

${ }^{18} \mathrm{Co}$-administration is when higher levels of government direct lower levels to undertake tasks and functions. The higher level of government provides the costs, means, infrastructure and human resources to carry out the tasks. The lower level of government is obliged to report to the higher level of government regarding the execution of these tasks or functions.
} 

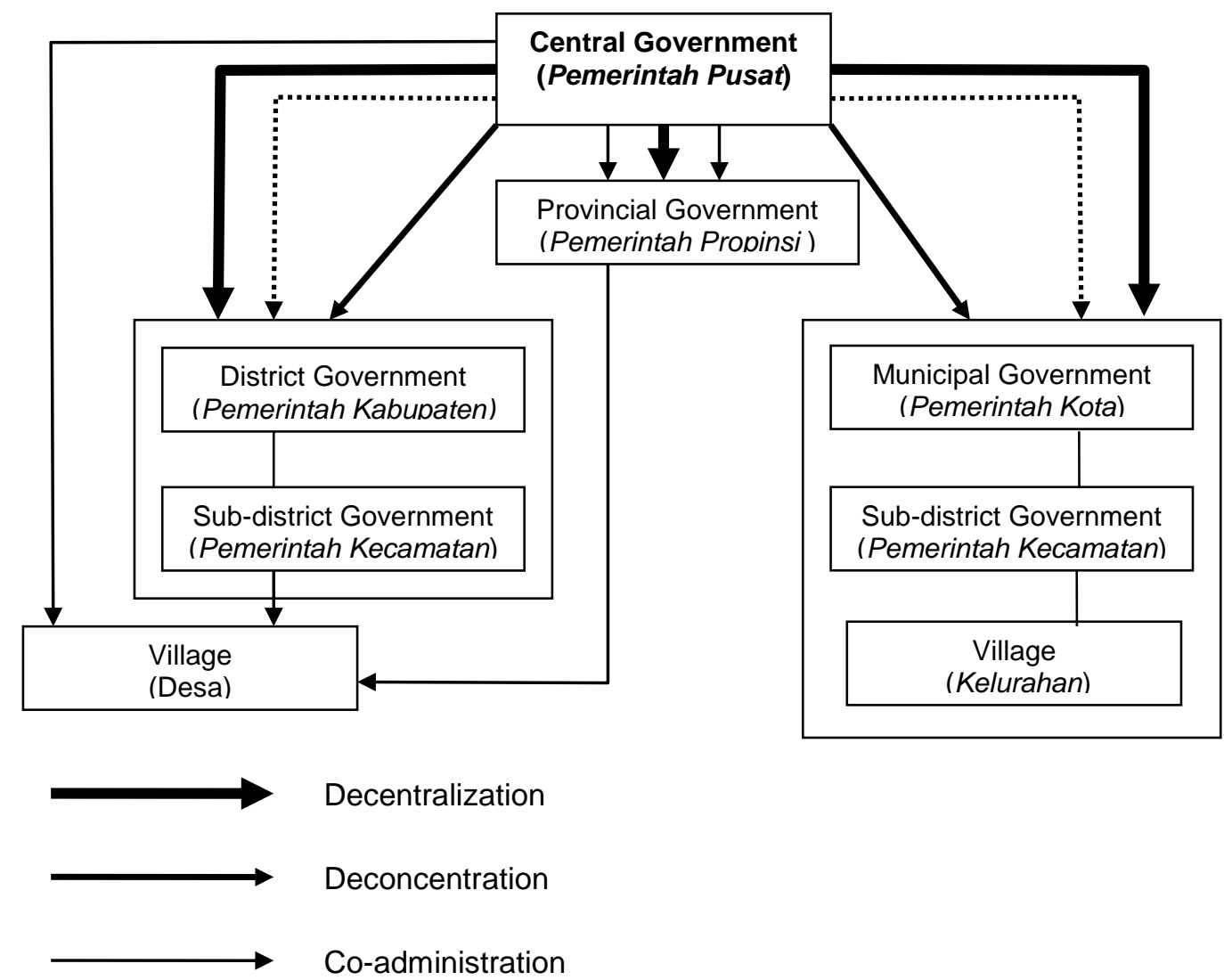

Amidst a plethora of changes, the new laws initially allowed for the locally contentious and politically powerful positions of Regional Heads (Kepala Daerah) to be appointed by local parliaments rather than by the provincial government representing central government interests which had been the case under the New Order. Decentralization and other new legislation also allowed for the 'blooming' (the lexical meaning of pemekaran - carving out of new regions) of new provinces, districts, sub-districts, villages, hamlets, and wards. ${ }^{19}$ Later, Law No. 32, 2004 revised the decentralization laws allowing for the direct popular election of Regional Heads, rather than by vote of the regional parliaments which was stipulated in the 1999 legislation. At the same time, the revisions rolled back the number of new provinces and districts that could be considered for formation and ratification by the national parliament in any one year, and modified the criteria, which must be met to form these new administrative areas, although the phenomenon of pemekaran continues to this day.

Prior to and during the post-1998 transition, there has been an increased assertion by minority ethnic groups of their interests and separate identities, which they claim to be of parallel importance to their national identity as Indonesians. Legislative change has created the space for these debates to surface and for local needs to be accommodated. However, groups that may be labelled minorities when compared with other groups in the national context, often have majority representation at the local level. It is on these

\footnotetext{
${ }^{19}$ Such legislative changes were also supported by amendments to the 1945 Constitution (Undang-Undang Dasar 1945 - UUD1945), which were intended to strengthen regional autonomy For example, in the Second Amendment, articles 18,18A, and 18B grant the broadest authority possible to the provinces, kabupaten, and kota, without differentiating the authority according to level of government. Kompas (2002, 12 August) 'Undang-Undang Dasar Negara Repubik Indonesia Tahun 1945 dan Perubahannya', p29-30.
} 
grounds, in the current era of decentralization that they are staking their claims. With regional autonomy, local politics is flourishing and consequently local identity politics are paramount in minority-majority claims and access to leadership positions. Two particular aspects of the decentralization process - the formation of new administrative areas as well as direct elections of the executive at the district level- shall be examined in a case study in the next section.

\section{Decentralization and its Impacts on Conflict Management: The Case of Central Sulawesi}

\section{Regional variation in the outbreak of violence}

Since the end of the New Order, between 1999 and 2004, reaching a peak between 2000 and 2002, large-scale communal violence broke out in Central and West Kalimantan, Ambon and North Maluku, and Central Sulawesi provinces, amongst others. ${ }^{20}$ Varshney et al. (2004) put the estimated death toll from collective violence at over 10,700 between 1990 and 2003 with the bulk occurring in the later part of the period. While the country is approximately 85\% Muslim and 10\% Christian, encompassing some 300 larger ethnic groups, in many (but not all) of the districts where conflicts are taking place the size of the ethno-religious groups is relatively balanced, that is, ethno-religious groups are concentrated regionally, and nationally-measured minorities are often local majorities. All of these communal conflict regions are outside of Java. In some cases, the ethnic groups with ancestral roots in the districts are numerically larger than that of spontaneous migrant groups (often from the same island or neighbouring islands) or sponsored transmigrant groups from the populated islands such as Java. ${ }^{21}$ In other cases, local majorities do not follow the majority religion of the country or the province.

Central Sulawesi is one of the most ethnically and religiously diverse areas in Indonesia, with a total population of 2,294,841 people in $2005 .^{22}$ It is one of a number of provinces situated on the island of Sulawesi, a large island in north-eastern Indonesia. Approximately $30 \%$ of the population of the province inhabit the inland regions, much of which is mountainous, while $60 \%$ live in coastal areas and a further $10 \%$ on the smaller surrounding islands which also form a part of the province, all of which influence the socio-economic environment in each area (BPS:2004)..The province is religiously heterogeneous, with religious adherents for the most part being Muslims (78.4\%) (ibid), although many Christians are found in highland areas where there was a strong missionary presence. There are 10 districts in the province at present, including recently formed Sigi district (2008), as well as the municipal capital Palu. This research was conducted in Poso and Donggala districts in Central Sulawesi. Both districts have a large concentration of ethno-religious minorities (measured nationally) which practice

\footnotetext{
${ }^{20}$ Conflicts of a more separatist nature have also escalated in Aceh and Papua - where sections of the populations in these provinces battle for greater access to resources and self-governance/determination. Smaller scale violence has been present all over Indonesia, particularly in West and East Java, East Nusa Tenggara, Riau, and other provinces. It has partly taken the form of waves of vigilantism, and partly intergroup violent and non-violent disputes similar to the disputes which proceeded the mass escalation of violence in the 'high-profile' conflict provinces. While the rumblings of these conflicts were present before the end of the regime (often preceded by smaller outbreaks of violence), they peaked following the end of the New Order.

${ }^{21}$ Transmigrant groups are often made up of Javanese people who were given incentives to move to periphery islands to decrease population pressures on Java island.

${ }^{22}$ http://demografi.bps.go.id/versi1/index.php?option=com tabel\&kat=1\&idtabel=111\&Itemid=165, accessed on 2 December, 2008.
} 
Christianity. Such district demographics challenge the status quo of provincial politics which is dominated by the larger Muslim ethnic groups.

Over the past eight years, violent conflict has taken place in several regions in Central Sulawesi: either as incidents of large-scale collective violence or smaller-scale incidents of violence between individuals, all resulting in loss of lives and property. Much of this has been concentrated in the Poso district, where the Muslim/Christian groups were almost equal in size at the onset of the conflict. The triggers of some of the major incidents of violence between 2000 and 2002 were youth clashes and seemingly small incidents between individuals, which resulted in the loss of some 2000 lives and widespread property destruction. ${ }^{23}$ However, local grievances around economic competition, corruption, political marginalisation of particular ethno-religious groups, and to some extent supra-local interests, form the backdrop to the clashes between local groups. By the height of the conflict, despite such political and economic roots as well as competition between ethnic groups, people were organised and mobilised around their Muslim and Christian identities, with all groups claiming indigeneity in the region. ${ }^{24}$ Conflict has also taken place in other districts such as Parigi Moutong, and Donggala, but has never escalated and incurred the same violent outcomes as the episodes of conflict in Poso.

Bertrand (2004) argues that the opportunity to voice grievances with the Suharto regime began to rise in 1996 with the emerging discourse on succession for the aging President. This, he argues, explains the escalation in violence throughout the archipelago at the time. Debates over Suharto's successor indicated a potential end to the status quo and the opportunity for different ethnic and religious groups to increase their demands, renegotiate their rights to representation, voice, and resources through the state (Bertrand, 2004). The discussion in the previous section of historical grievances towards repressed regional identities and the marginalisation of some groups from the state gives merit to these arguments, helping to explain the outbreak of violence in Central Sulawesi.

Furthermore, Bertrand (2004) and Hefner (2000) argue that the rise in Muslim-Christian violence in the 1990s is linked to the embrace of Islam and Muslim intellectuals by Suharto in the late 1980s. Grievances, while local, had linkages to the national sphere of politics, patronage, and change. Cote (2005: p.4) highlights that from 1970 until the 1990s, New Order development policies often favoured the different groups in Central Sulawesi that gave patronage to the regime. This included favouring groups outside of the GKST (Gereja Kristen Sulawesi Tengah - Central Sulawesi Christian Church) synod, potentially undermining its power. Throughout the New Order regime, outbreaks of violence were not uncommon between Muslims and Christians as well as between migrant and indigenous groups in Palu (the capital) and Poso, but these episodes were promptly repressed by the government (Human Rights Watch, 2002). However, Cote contends that during the early 1990s, patronage from Jakarta shifted towards GKST, partially stimulating the Islamic claims to power during the violence between 1998 and 2004. In the final days of the New Order, Islam was increasingly privileged over other religions at the national, provincial and sometimes local level, leading to resentment within the Christian communities (Aragon, 2001: 54) as patronage shifted toward Muslim

\footnotetext{
${ }^{23}$ Varshney et al., 2004; interviews with Muslim and Christian leaders in Poso, May 2005.

${ }^{24}$ For more information on the conflict in Poso see: Acciaioli (2001); Aragon,(2002); Aragon, (2001), Cote (2005); Human Rights Watch (2002) ; YAPPIKA (2003), ICG (2005), and Varshney et al. (2004).
} 
groups. The situation was compounded by migration dynamics whereby mostly Muslim migrants were increasingly viewed as demographic threats to the historically Christian domination of the highlands now that they had privileges from the state.

However, while Bertrand's 'critical historical junctures' help explain the outbreak of violence in the country, they do not explain the forms and intensity of violence, nor why conflicts escalated so badly in some areas such as Poso, but not in other areas where there was similar re-negotiation of access to the state by local groups such as in Donggala where this research was also conducted. Van Klinken (2007: 9) links conflict in Poso and in other conflict communal areas to the role of local elites opportunistically mobilising resources and inciting local constituencies along ethno-religious lines for their own interests in local power struggles, particularly in terms of dominating the bureaucracy. While this was an important factor explaining the escalation of conflict into violence in Poso, it ignores the agency of group members in sustaining the violence, and again, does not explain why it did not break out in other areas where elites also attempted to mobilise around sensitive identities but were unsuccessful. While the discussion below does not concentrate on how mobilization took place in the conflict in Poso, it does focus on one further factor that helps explain regional variation in the outbreak of violence and the incentives of elites and groups members alike to mobilize for violence at the critical historical juncture in Indonesia, that being horizontal inequalities.

Horizontal inequalities refer to the economic, social, and political inequalities between culturally defined groups (Stewart et al.: 2008). ${ }^{25}$ Group identities, and the real and perceived relationships between groups, are frequently a central feature of contemporary armed violence. While most people exhibit multiple identities that transect gender, ethnicity, religion and geographic location, particular identities acquire political significance, according to historical and social factors. The historical section of this paper explains how ethno-religious identities have taken on such political importance in Indonesia. In some contexts group affiliation assumes such importance that it can lead individuals to fight and die in the name of identity, as has been the case in Poso. Furthermore, actual and perceived differences and inequalities between groups may be mobilized by political elites in order to initiate armed violence.

Gurr $(1970,1993)$ argues that relative deprivation of a group is a necessary precondition for civil strife of any kind. However, Gurr's work is focused on how the deprived mobilize for violence. Whereas, researchers on horizontal inequalities see a role for both the deprived and those in a position of power or privilege mobilizing for violence, either to protect the status quo and to change it. Stewart (2002) and Stewart, Brown and Mancini (2005), Stewart (2008) and Østby (2008) provide evidence of the links between horizontal inequalities and the propensity for violent conflict. Based on the case of Indonesia, Mancini (2005) argues that inequality between ethnic groups represents a potentially important channel through which ethnic diversity can lead to violence. Yet, as Stewart $(2000,2008)$ rightly points out, there are many societies where groups with sharp inequalities live side by side and do not experience widespread collective violence. Given these findings, the following section seeks to explain why inequalities in some instances are linked to violence in parts of Central Sulawesi and not in others.

\footnotetext{
25 These are distinct from 'vertical inequalities' which are typically described as inequalities between individuals.
} 


\section{Poso and Donggala: Demographics, grievances and conflict}

Prior to the onset of the conflict in 1998, the population of Poso was split almost evenly between Muslims and Christians (BPS, 1998). Prior to the conflict, by all qualitative accounts, community relations (both along ethnic and religious lines) were friendly, with religious and other festivals celebrated together and many of the villages being mixed ethnically and religiously. By the second and third phases of the conflict in 2000, mobilisation overtly took place along religious lines (although, the historical causes were around economic and political competition) and the clashes between groups during this period have been described by many locals as inter-religious warfare. ${ }^{26}$ The Christians mainly involved in the conflict were Protestants of the Pamona ethnicity and smaller groups of other ethnicities from the highlands. Supporters on the Christian side also came in neighbouring districts and other parts of the province during the armed warfare, in some cases bringing arms. The Muslims were predominantly coastal Bugis, Gorantalese, and in later phases of the conflict, the Javanese. While many of the latter three groups have been in the area for generations, some still consider these groups to be 'newcomers' based on local migration patterns. Again, during the conflict Muslims from neighbouring areas such as Parigi, Palu, the southern parts of Sulawesi island, and even Java entered Poso either to build numbers or to bring arms during the conflict. Thus, in forming the two major religious blocks involved in the conflict, there were coinciding ethnic and religious divides. No unifying ethnic or religious identity could be used to bridge the groups. These problems further reinforced by a local 'us-them' discourse around who can be considered locals and who are considered 'newcomers' given the local migration patterns (although this was largely spontaneous migration). These large blocks, with no cross-cutting ethnic or religious identities are an important component of explaining how grievances around horizontal inequalities discussed below could add to the factors driving the conflict

Donggala is the second district examined the study. Donggala, once the seat of the provincial capital and located next to the current capital, Palu, also has a high level of ethno-religious diversity and some local-level conflict (although this has never escalated to the extent that it did in Poso). Similar to Poso, the district is resource rich and ethnically diverse. Donggala is $70 \%$ Muslim and approximately $25 \%$ Christian (mainly Catholics). The demographic makeup of Donggala is of mixed ethnicities, with the majority professing the Muslim faith which coincides with the trend in the province overall. There are a number of different indigenous ethnic groups in the region, in particular the largest group, the Kaili, and the Kulawi. These local groups along with other smaller local ethnicities make up around two thirds of the population of the district. Ethnic identity in this region is fairly fixed along patrilineal lines, although the qualitative interviews revealed that younger generations with mixed parentage in some cases also identify with their mixed heritage and claim it as such, although marriage ceremonies follow the traditions of the ethnicity of the father. Switching faiths usually only occurs through marriage, with the woman often adopting the religion of her husband. The mainly Muslim Bugis migrants originating from South Sulawesi, also account for around $10 \%$ of the population, with some being present in the region for several generations. However, in contrast to Poso, there is a unifying ethnic identity which cross-cuts differences in religion in Donggala: the Kaili. The Kaili in the coastal regions are mainly Muslim and the Kaili in the highlands are mainly Christian (as are the Kulawi).

\footnotetext{
${ }^{26}$ For a brief chronology of the phases of the conflict, see Brown and Diprose (2009).
} 
The in-depth interviews carried out in Donggala between 2005-7 revealed that grievances surfaced following the end of the New Order amongst the different ethnic and religious groups in terms of their access to economic opportunities and the state. There was perceived favouritism for Muslim Kaili groups (who also have a strong presence in provincial level politics) in terms of access to the state and occupying higher level executive positions. This particular view mainly emerged from the more educated and politically active interviewees as opposed to members of poorer groups. The Bugis were also perceived to dominate trade sectors and key employment opportunities, and also have strong links to the state. The Kulawi - with their high levels of education resulting from many of the church sponsored schools - were seen to be able to access to the state in terms of civil service employment, but rarely higher level executive positions. Several interviewees explained that at various points in the years following the end of the Suharto regime, elites had tried to mobilise around religious identity but were unable to gain sustained grass roots support. They explained that when religious differences were cited, ethnic similarities were emphasised, especially amongst the Kaili.

Similarly, the qualitative interviews conducted in Poso between 2005-7 revealed two of the major complaints underpinning the onset of the conflict (although there are many more) in 1998. The first was the disruption of informal power-sharing agreements between Muslims and Christians which traditionally involved rotating the District Head position between the two groups. Since the 1990s, a Muslim District Head had been in place for two consecutive periods, and the same person was again appointed in 1998 in the month preceding the first outbreak in December of the inter-group violence. Second, there were grievances surrounding the marginalisation of certain groups - predominately Christians - from the district legislature (elected) and the executive (all appointed prior to 2004), particularly the key civil service positions in charge of civil service appointments and the allocation of government projects and contracts, all of which created the space for the favouritism of particular groups in particular sub-districts and villages. Entangled with this was the issue of the high-level corruption involving Farmers Credit Union (KUT) funds in 1998 by those close to the district executive.

Many respondents in the in-depth interviews claimed that such favouritism, the domination of the executive by particular groups, and subsequent corruption have had an adverse affect on the standard of living of those who have been marginalised from such access to resource allocation and decision making. Many respondents in the interviews from both sides of the conflict give these reasons as an explanation of how a seemingly normal fight between youths of different faiths began to spread with each phase of the conflict and took on religious overtones, as the broader grievances began to be channelled through the disputes between the youth. While religion is the first identity label used to distinguish 'us' and 'them' when articulating such complaints in Poso, there are also nuances of ethnic marginalisation and claims of indigeneity and the associated rights of particular ethnic groups in the region compared to the 'newcomer' status given to some migrant groups (although these claims of indigeneity are locally highly contentious, where migrant status is selectively applied and some of the newcomer groups have been in the area for several generations). Evidence of the ethnic overtones of the conflict can be found in the refusal of many of Pekerehua ethnic group, also Christian, but Catholic, refusing to engage in the warfare. 


\section{Poso and Donggala: A comparison of economic, social and political inequalities}

How then do these qualitative findings fare in terms of aggregate perceptions of inequalities in each district based on a survey conducted in 2006 by CRISE at the University of Oxford? ${ }^{27}$ On the one hand, this survey was conducted at a time when tensions were beginning to subside in Poso (individual acts of violence continued to occur at the time, including shootings, bombs, and knife assaults). On the other hand the findings from the survey are in line with the qualitative discourse of complaints about the roots of the conflict and the marginalisation of particular groups from political and economic processes. Furthermore, archival documents, including confidential complaints letters written to district officials in the 1990s examined during the research also elucidate the strong perception that particular groups were excluded from higher level positions in government, and that executive members of the district administration channelled government resources to particular sub-districts where they had patronage of particular ethno-religious groups.

\section{Economic inequalities}

The evidence suggests that there are wealth inequalities between the religious groups which likely contributed to the impetus to mobilise during the conflict. A wealth index was created from the results of the survey based on ownership of household assets. First, the results presented in Table 1 indicate that Donggala respondents are significantly less wealthy than Poso respondents $(\mathrm{p}<.05)$. About half of Donggala respondents fall into the bottom 4 deciles - which is the cut-off used in the paper to define the poor - of the wealth distribution of the pooled sample (both Donggala and Poso respondents) compared to $33 \%$ for Poso. Likewise, $33.2 \%$ of Poso respondents belong in the top three deciles which define the rich - of the overall distribution compared to only $15.4 \%$ of Donggala respondents. Thus, the evidence suggests that violent conflict is not confined to only poor districts exhibiting ethno-religious diversity, as violence took place in a diverse district which was less poor than its diverse neighbour.

\section{Table 1: Weighted wealth index by religion, Poso and Donggala $2006^{28}$}

\footnotetext{
${ }^{27}$ The CRISE survey, carried out in 2006, involved random household and individual selection with stratification being used at the sub-district level. The choice of Poso and Donggala district was made based on two criteria: 1) Poso and Donggala are neighbour districts with similar geography, natural resources, and degree of urbanization, and were the most similar districts in the province in terms of ethno-religious diversity; 2) Poso and Donggala have a very different history of communal violence: whereas the former has experienced very serious ethno-religious violence over the last decade, in the latter social tensions has never degenerated into high-scale violence. Therefore, the socio-economic similarities between the two districts are expected to make comparisons in perceptions and attitudes more meaningful. A total of 600 interviews were carried out, equally divided between the two districts. A further within-district stratification took into account the degree of ethnic or religious diversity (diverse and homogenous areas) within each district. The intersection between these two stratification criteria produced six different strata which largely coincide with sub-district borders (one diverse strata, one mainly Christian strata, and one mainly Muslim strata in each district).

${ }^{28}$ We were faced with the potential problem that the Donggala sample was significantly more rural than the Poso sample (73\% rural compared to $57 \%$ for Poso). This was mainly due to the big discrepancy in the urban/rural split in the religiously diverse strata. The diverse stratum in Poso district is $67 \%$ urban while the diverse stratum in Donggala is only $23 \%$ urban. A preliminary analysis of the data revealed that urban/rural status significantly affected some of the key variables that the survey sought to investigate and in particular perceptions of own identity and attitudes toward violence. Thus the results were re-weighted: the equivalent of 30 respondents from rural diverse strata in Donggala, where there was slight oversampling, were "reallocated" to the homogenous stratum through reweighting. Moreover, as we oversampled in this sub-
} 


\begin{tabular}{|c|c|c|c|c|}
\hline Wealth Index & \multicolumn{2}{|c|}{ Poso \% } & \multicolumn{2}{c|}{ Donggala \% } \\
\hline Bottom 4 deciles & \multicolumn{2}{|c|}{33.3} & \multicolumn{2}{c|}{48.3} \\
\hline Top 3 deciles & \multicolumn{2}{|c|}{33.2} & Muslims & Christians \\
\hline & Muslims \% & Christians \% & 42.5 & 51.6 \\
\hline Bottom 4 deciles & 26.9 & 45.6 & 28.1 & 32.1 \\
\hline Middle 3 deciles & 30.1 & 28.8 & 29.4 & 16.3 \\
\hline Top 3 deciles & 42.3 & 25.6 & \\
\hline
\end{tabular}

Second, the wealth distribution within and between groups seems to be important when we compare the districts and the likelihood of violence. Table 1 shows that significantly more Christians fall into the poor deciles than Muslims in Poso $(\mathrm{p}<.05)$ but not in Donggala (differences are not statistically significant) where the grievances did not escalate into violence. This holds in the case where the wealth deciles refer to the overall wealth distribution (pooled sample, not presented above) as well as when each district is considered separately $(\mathrm{N}=300$, presented above).

Table 1 further demonstrates a significant proportional disparity between the number of wealthy Muslims and the number of wealthy Christians in each district, but this is more heightened in Poso. The results indicate there are significantly more wealthy Muslims in Poso, compared to Donggala, but the difference is not significant between the districts for Christians.

Finally, in Donggala, the between religious group disparities of the poor and rich did not hold across both clusters of deciles; that is, there was only a significant $(p<.05)$ wealth disparity between the proportion of Muslims versus Christians in the 'rich' deciles but not between the proportion of each group in the 'poor' deciles. However, in Poso, the proportion of wealthy Muslims was significantly greater than rich Christians $(p<.05)$ and the proportion of poor Christians was significantly greater than Muslims. Thus, in the area where conflict took place there were coinciding grievances between the wealthy and poor around economic horizontal inequalities.

In Poso, at the "critical historical juncture" in Indonesia's history, grievances and interests around wealth inequalities based on religious group membership amongst the elite (wealthy) and poor likely provided impetus for mobilisation as the qualitative evidence suggested. On either side of the conflict, be it to challenge or protect the status quo in the distribution of wealth, elites had incentives to mobilise and the poor had incentives to organise or be mobilised around sensitive identities - a perfect catalyst for conflict given the history of inter-group tensions. In Donggala, there was no significant difference in the proportional number of the poor in either religious group, and thus there was less impetus to engage in conflict on the part of grass roots groups. In fact, the qualitative interviews revealed that when elites did try to mobilise around sensitive identities in Donggala, they were unable to gain much grass roots support.

district this adjustment will bring the sample size closer to what it would have been had we sampled with probability proportional to population size (PPS). Consequently, the undersampling in the other strata is rebalanced and more in line which its district' population share. A similar process was used for the equivalent of 20 respondents in the diverse stratum in Poso which again was slightly over sampled. 


\section{Political and social inequalities}

The complaints of favouritism and the potential economic and political gains which can be achieved through accessing the public sector pervaded public perceptions and discourse at the time this research was conducted. This was evident in the discussions around the causes of the conflict and also in the pre-conflict grievances evident in archival documents. In the qualitative interviews in both districts, grievances around unequal access to the state featured strongly, but less prominent were grievances around social inequalities, such as access to education. In Donggala, when complaints did arise around inequalities in terms of either access to the state or other forms of wealth, services, and livelihoods, it was mainly around how particular ethnic groups dominated particular sectors. However, in Poso both ethnicity and religious identity were perceived to be relevant to achieving access to public and private resources.

Figures 2 and 3 below show how aggregate perceptions fared from the results of the survey in terms of ethnic and religious group membership affecting the means of improving standards of living. Ethnicity and religion were perceived to determine access to public and private wealth and advancement in both districts. However, there was some variation, with significantly more people perceiving ethnic group membership to affect chances in some sectors in Donggala, whereas religious difference was more pronounced as a driver of access in Poso, especially in terms of access to the public sector. 
Figure 2: CRISE perceptions survey: Perceptions of ethnic identity and its impact on opportunities

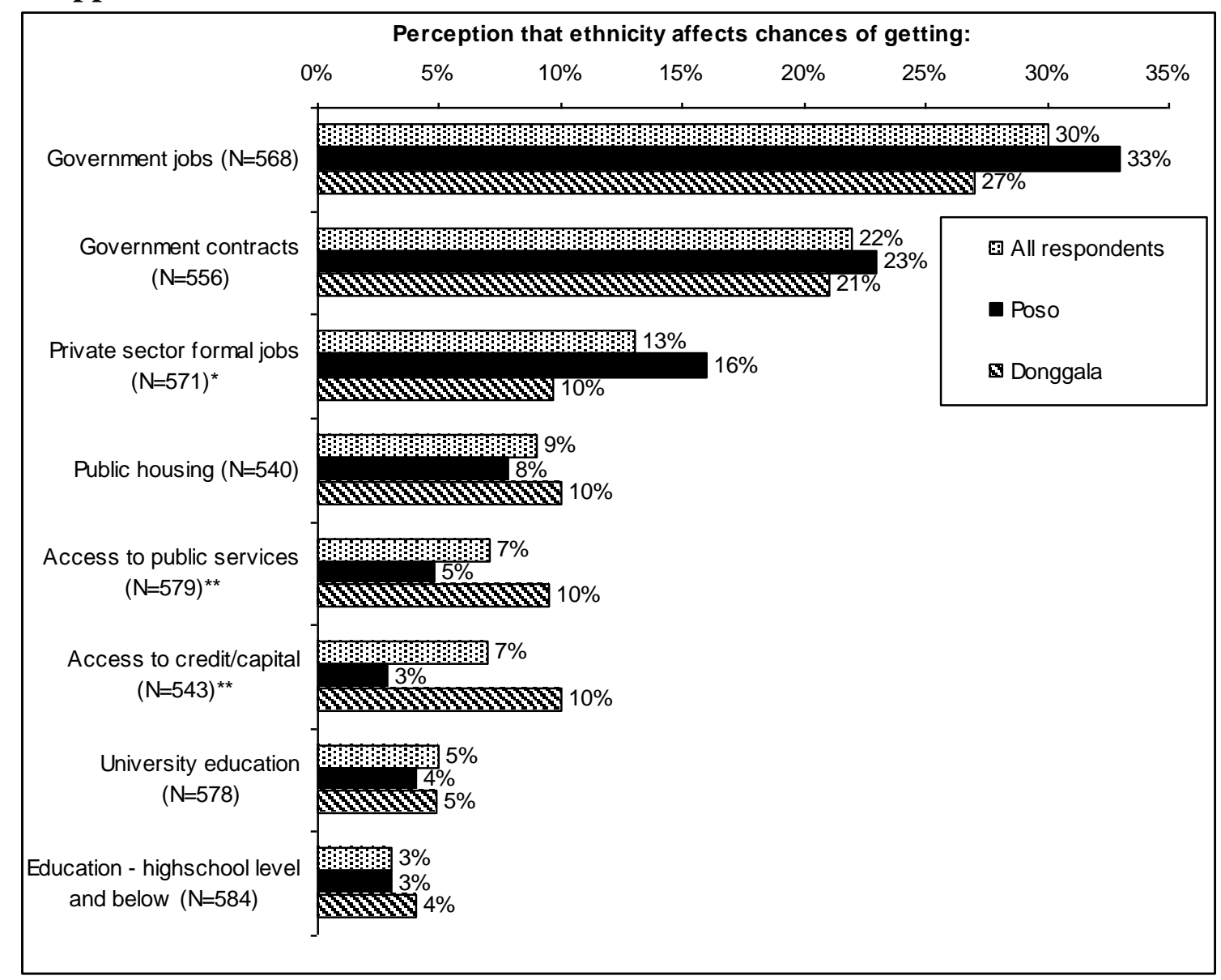

* significant to $10 \%$ level (p<.1), ** significant to $5 \%$ level $(\mathrm{p}<.05), * * *$ significant to $1 \%$ level $(\mathrm{p}<.01)$. All expected and actual cell counts were $>5$.

Approximately one third of respondents saw ethnicity affecting chances of getting government jobs and nearly one quarter saw it affecting chances of getting government contracts, with no significant difference between districts. Furthermore, ethnicity is perceived some of the population to affect chances of getting formal employment in the private sector (more so in Poso) and public housing in both districts. However, significantly more people in Donggala saw ethnicity affecting access to public services and credit compared to Poso. 
Figure 3: CRISE perceptions survey: Perceptions of religious identity and its impact on opportunities

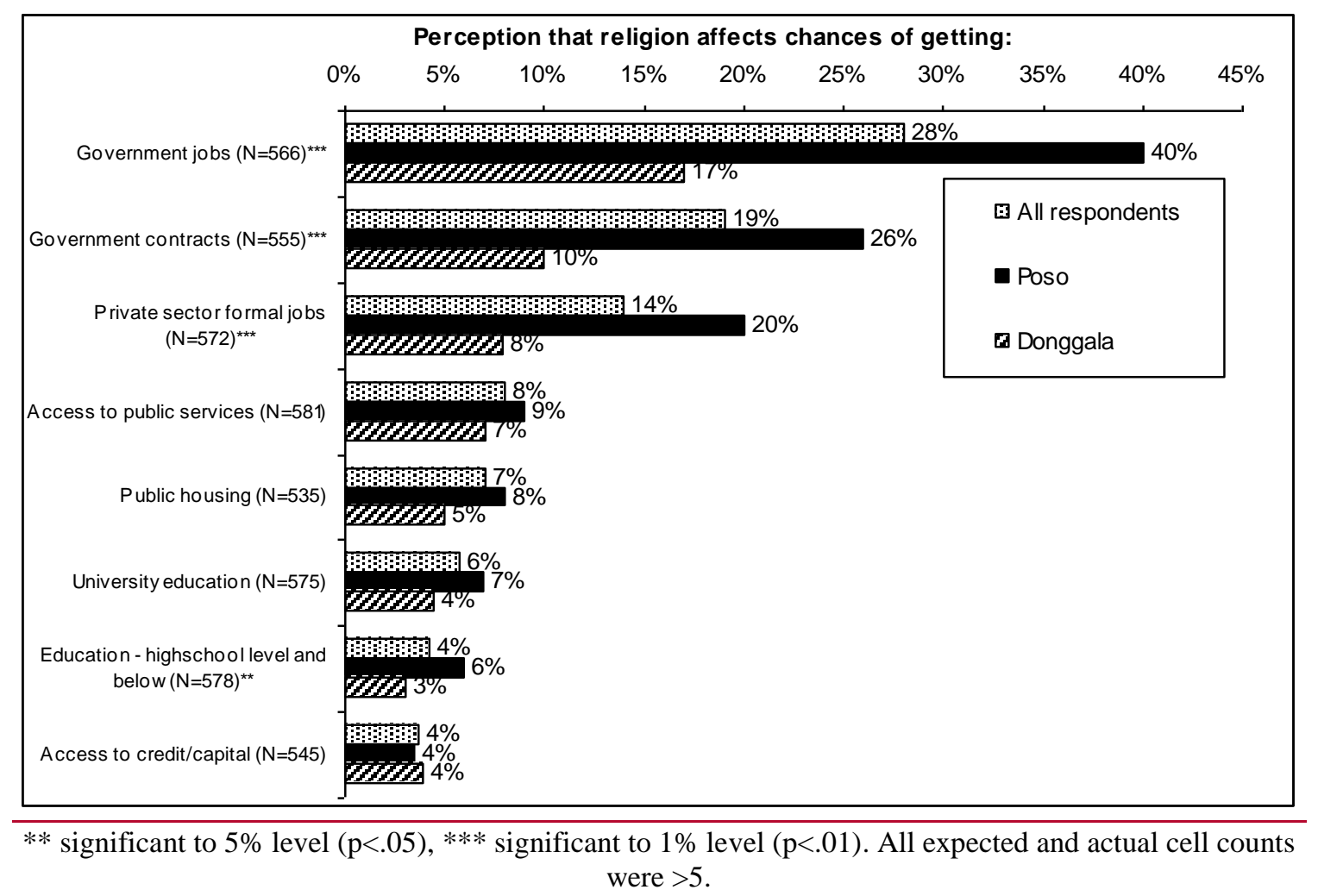

Overall the proportion of people who saw religion affecting chances of accessing public and private sector opportunities was roughly similar to those who perceived this to be the case with ethnicity. However, the proportional differences in the number of responses on religious identity were significantly greater between districts compared to ethnicity (see Figure 1), particularly in terms of accessing the public sector $(\mathrm{p}<.01)$ and private sector employment $(\mathrm{p}<.01)$. These were grievances also cited in the qualitative interviews as a reason for the conflict.

In order to investigate the notion of differences in access to the state being linked to sensitive identities and potentially conflict, the survey asked if particular groups were closer to (or favoured by) the government, and if particular groups were discriminated against by the government. It is here that the grievances around ethnic and religious differences become more marked between the two districts and potentially help explain how conflict could have escalated in one district and not the other by providing an impetus for mobilisation of grievances around horizontal inequalities.

It is evident from Figure 4, that overall one third of respondents across the districts thought that particular groups were closer to the government, but significantly more people thought this was the case in conflict-affected Poso $(\mathrm{p}<.01)$ - nearly half of Poso respondents compared to around one quarter of Donggala respondents. However, similar to the results above, ethnic differences were significantly more likely to be a perceived difference in Donggala $(\mathrm{p}<.05)$, whereas it was religious group differences that were cited in Poso $(\mathrm{p}<.05)$. Political and class cleavages featured in both regions with little significant difference, indicating that this is potentially a more pervasive problem across 
of Indonesia, rather than something which explains how grievances emerge in some places and not others and sensitive identities are mobilised.

Figure 4: CRISE perceptions survey: Perceptions group closeness to the government

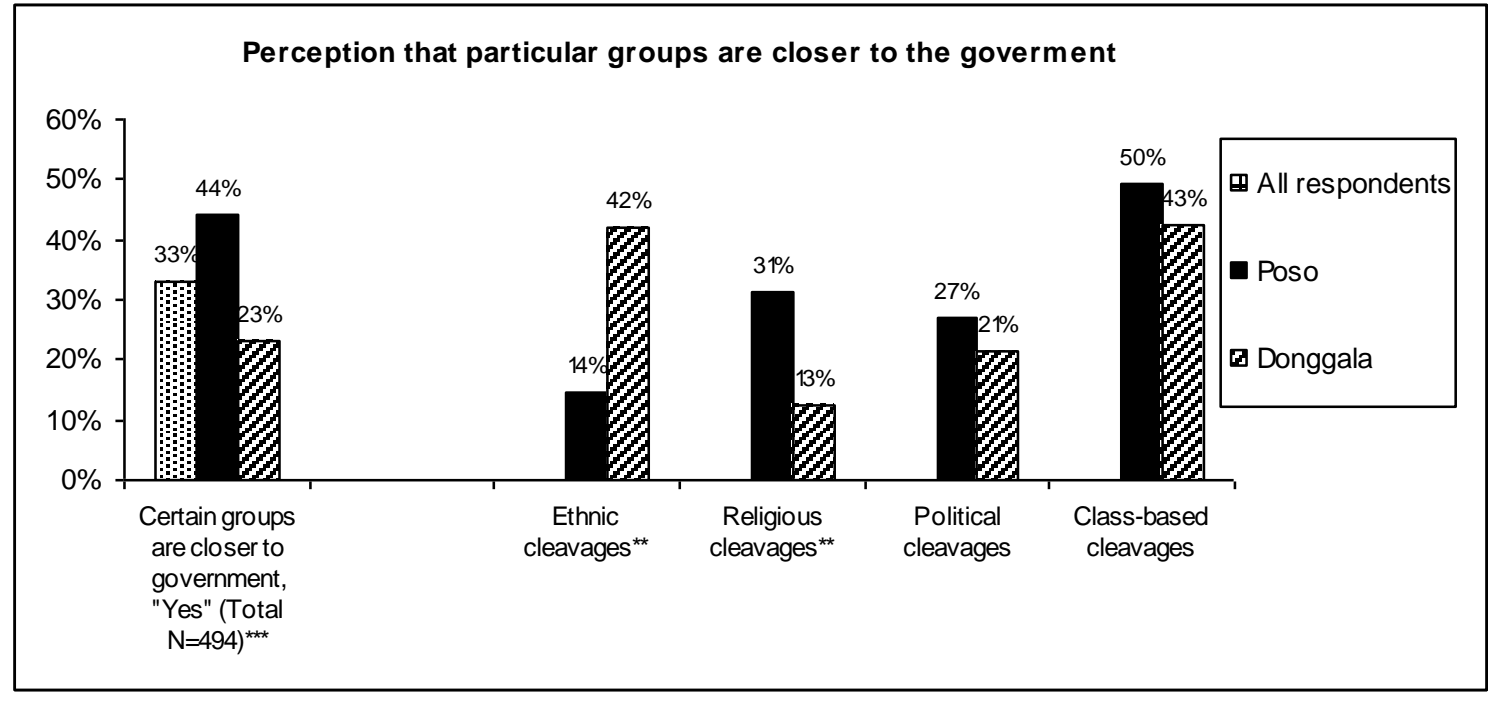

** significant to $5 \%$ level $(\mathrm{p}<.05), * * *$ significant to $1 \%$ level $(\mathrm{p}<.01)$. All expected and actual cell counts were $>5$.

Figure 5: CRISE perceptions survey: Perceptions that groups are discriminated against by government

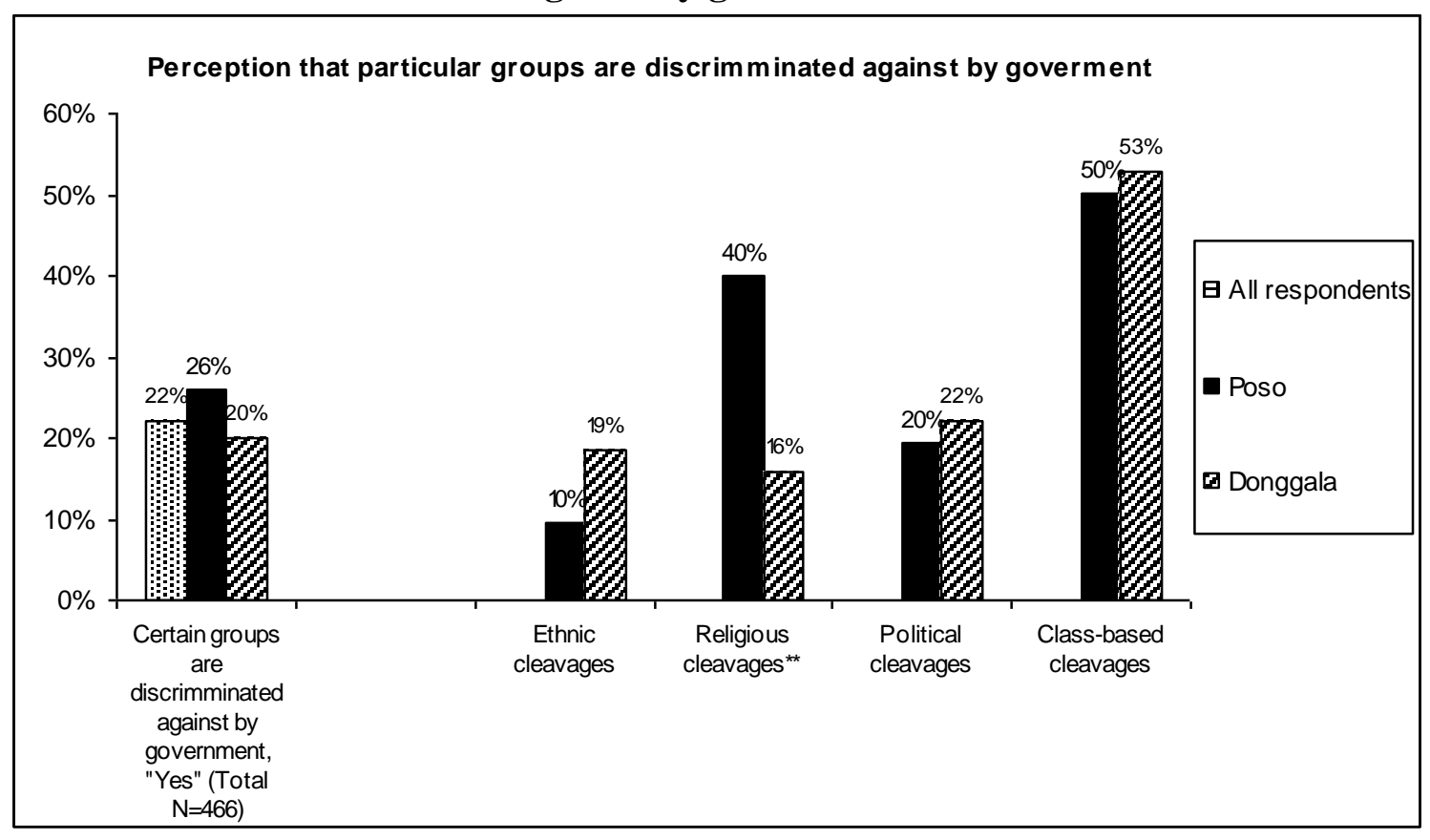

** significant to $5 \%$ level $(\mathrm{p}<.05)$, *** significant to $1 \%$ level $(\mathrm{p}<.01)$. All expected and actual cell counts were $>5$.

Figure 5 above demonstrates another interesting finding from the research. First it shows that one quarter of respondents think that some groups are discriminated against by government. While there was no significant difference between districts in this view overall, there was a significant difference in that it was more likely to be linked to religious group identity in Poso $(\mathrm{p}<.05)$. 
Other questions asked if particular groups dominated: the district government, the provincial government, the district civil service, and the local trade/business sector. 39\% of respondents said that particular groups dominated the district government. While there was no significant difference between districts overall, Poso respondents were significantly more likely to list religious groups and those with political affiliations as dominating the district government $(\mathrm{p}<.05)$, but again Donggala respondents were more likely to mention ethnic cleavages $(\mathrm{p}<.05)$. Similarly, $35 \%$ of respondents overall said that particular groups dominated the district civil service (no difference between districts), but political and religious differences were significantly more likely to be mentioned in Poso, and ethnic differences in Donggala. One third (33\%) of respondents perceived that particular groups dominated the provincial government. Religious cleavages again were significantly more likely to be cited in Poso and ethnic cleavages in Donggala $(\mathrm{p}<.05)$. More than half of all respondents $(54 \%)$ perceived that there were particular groups that dominated local trade and this perception was significantly more likely in Donggala (71\%) compared to Poso (32\%) which was significant to the $1 \%$ level, again the mentioned cleavages were ethnic. Thus, when it comes to access to public resources, religious identity and political patronage (through closeness to high ranking officials, family ties, and party membership) are interlinked in Poso in terms of greater likelihood to access the state, whereas ethnic cleavages are prevalent as a means of access in Donggala. Political affiliation is less prevalent in accessing private sector resources through trade, but religious identity is a prevalent factor in Poso and ethnic cleavages are more relevant in Donggala.

When we view the perceptions of political inequalities overall from the survey results it confirms the qualitative findings. First, that both ethnicity and religion matter in Poso in terms of grievances around access to the state, with religious identity being more likely to be linked not only to favouritism, but also discrimination against particular groups. Discrimination becomes important here as it implies there is proactive marginalisation of groups on the part of agents of the state. When political patronage enters the arena in terms of which groups can dominate parts of the administration, a more fiery mix is created, as has been the case in Poso. These inequalities around access to the state were the some of the same complaints cited as the major drivers of the conflict in the qualitative interviews and in the work carried out by other researchers (Acciaioli, 2001; Aragon, 2001; Human Rights Watch, 2002; YAPPIKA, 2003; Cote, 2005), along with corruption. Given that certain groups are perceived to have dominated the state, its resources, and were implicated in corrupt practices prior to the onset of the violence, it is not surprising that conflict escalated in the district. However, in contrast, only ethnicity is perceived to matter significantly in Donggala and only in terms of easier access or domination of the state or private sector, rather than proactive discrimination. Political affiliation and class differences seem to be present across the board as affecting access to public resources, and thus are unlikely to explain regional variation in the likelihood of conflict arising from such grievances.

Furthermore, it is likely that the interaction between economic inequalities between religious groups (present amongst rich and poor in Poso but only amongst the rich in Donggala) and perceived political inequalities between ethnic and religious groups in Poso, may help explain the outbreak of violence. This is especially the case when there were no bridging identities to unify groups in Poso as there are in Donggala where similar grievances were present. In the Poso conflict, blocks of people with coinciding ethno-religious identities and common grievances mobilised and were mobilised, 
partially explaining the conflict trajectory. Donggala also displays ethno-religious diversity and has experienced the same "critical historical juncture" as Poso, where groups could renegotiate the position vis a vis the state, but there are fewer incentives to mobilise several ethnic groups (seemingly the most salient form of difference based on survey results) along religious lines, and any efforts to do so are made more difficult as there are unifying ethnic identities that cross-cut religious divides.

\section{Poso: Decentralization and inequalities}

For comparative purposes, examining the administrative boundary changes in both Donggala and Poso is important for understanding how the changes brought about by decentralization have interacted with horizontal inequalities in the regions. The laws have been used at the local level as a conflict amelioration mechanism, reducing local, particularly political inequalities. However, at the same time, such changes with the laws are potentially a trigger for future conflicts. It cannot be said that decentralization is the single major force in reducing conflict in the province, particularly in Poso. However, carving out new regions within political institutional spaces allowed for by the legislative change has significantly affected population demographics, the creation of new administrative areas and control over natural resources, in turn affecting elite power struggles and alliance building as well as the struggles for representation of ethnoreligious groups in the local executive and legislature. Thus, decentralization has had some indirect impacts on the conflict dynamics in the region. Furthermore, the direct election of the executive provided for in the revised decentralization laws have changed the nature of local politics and representation at the district level, which in Poso at least was considered one root of the conflict (Human Rights Watch, 2002; Aragon, 2001).

With decentralization, a number of new districts, sub-districts, and villages have been carved out of existing territories in the region, partially as a conflict amelioration mechanism. Several Christian and Muslim sources confirmed that while there was some discontent amongst Muslim elites particularly about the formation of Tojo Una-Una distict, the proposal to form both Morowali District in 1999 and Tojo Una-Una in 2003 was broadly accepted and endorsed by the district parliament, with one reason being to ease conflict pressures. The region-splitting process is also a part of a broader strategy to increase the number of districts and sub-regions in order potentially to create East Sulawesi province (Tirtosudarmo, 2006).

District-splitting through decentralization has changed the demographics in Poso significantly. Carving out of Morowali District from the Poso District in 1999 not only reduced the number of Muslims in the district (although not as significantly as with the later formation of Tojo Una-Una district) but also, the informants in the qualitative interviews revealed, created more jobs and potential opportunities for old Poso elites in the new district, reducing competition between elites for power in Poso District. Immediately prior to the conflict and during its initial stages, many elite positions in Poso were dominated by Muslims, particularly from the Bungku and Mori sub-districts (this was confirmed by both Muslim and Christian sources). These two sub-districts were then incorporated into the new Morowali District, shifting some of the elite competition and the rough demographic polarisation of Christian and Muslim identities to the new district. 
Large-scale inter-communal clashes began to subside by the end of 2001 with the declaration of the Malino Peace Accord. ${ }^{29}$ This is not to say that the violence stopped, but rather that it changed form. In 2001 and for some of 2002, violence instead took the form of raids or attacks on villages, which involved burning down houses, rather than large, full-on clashes between groups, which had all but disappeared by the end of 2001 . Human physical violence then began to take the form of attacks against individuals through 'mysterious' shootings, killings and disappearances. ${ }^{30}$ It was also around this time that planning for the carving out of a second district, Tojo Una-Una, began to take place. Two elite sources from the different communities confirmed that the formation of the new district was sped up as a conflict-amelioration strategy to reduce some of the pressure in competition for elite positions and to meet some of the grassroots grievances pertaining to marginalisation. While this was met by some dissent on the Muslim side, which in recent years had dominated the executive in particular, again the district legislature fully endorsed the proposal. By 2003, Tojo Una-Una was formed, shifting the demographics in Poso to 65\% Christian and 30\% Muslim (BPS Poso, 2006). The Muslim population is still predominately found in coastal areas and the Christians in the highlands. This provided the opportunity for Christians, now the vast majority in the region, to increase their claims on the district executive and access to government and resources. To some extent, decentralization managed to ameliorate some of the local tensions by increasing the number of positions available for elites to access the state, and giving majority status to the local ethnic group claiming long standing marginalisation from government. This is important in the new era of democratisation in Indonesia where majorities gain greatest access to the state in absence of any quota system. Although, this is not necessarily the fairest or safest strategy as new minorities may become disgruntled in the future.

Aside from splits at the district level, a number of new sub-districts and villages have also been formed in Poso, most recently Poso Kota sub-district, where many of the physical clashes between groups once occurred. This sub-district has now been split into two with the formation of South Poso Kota. Poso Pesisir sub-district, another location of the violence, has been split into three sub-districts, shifting the Christian-Muslim majority lines. Both changes have created greater ethno-religious segregation at the sub-district and village level. At the village level, following the return of refugees from the intergroup phase of the conflict, many (but not all) of the once-mixed villages are religiously segregated, although there are efforts on the way for encouraging greater integration through building houses for returned refugees in mixed villages. This is also evident from the CRISE survey results (Figures 6 and 7), which demonstrate a high level of perceived

\footnotetext{
${ }^{29}$ The Malino Peace Accord had ten points of agreement: to cease all conflicts and disputes; to abide by due process of law enforcement and support the Government's efforts to impose sanctions on any wrongdoers; to request the state to take firm and impartial measures against any violators; to maintain peace, the two sides rejected civil emergency status and interference from outsiders; to respect one another in an attempt to create religious tolerance; that Poso is an integral part of Indonesia's territory. Therefore, any Indonesians have the right to come and live peacefully in Poso by respecting the local habits and custom; to reinstate property to their rightful owners; to repatriate refugees to their respective original places; to rehabilitate, along with the Government, the economic assets and infrastructures of the area; and, to respect all faith followers to implement their respective religious practices and beliefs as stipulated by the Constitution. In addition, the two factions also agreed to establish two joint commissions. One to deal with law and order, and the other to oversee social and economic conditions.

${ }^{30}$ Interviews with representatives from Yayasan Tanah Merdeka, LPSM, Poso Centre, KPKPST and other NGOs monitoring violence in the region (2005 and 2006)
} 
religious and ethnic segregation at the village level, a phenomenon which is not new in Poso but which has been strengthened as a result of the conflict. This is different from Donggala, which is perceived by more people to be ethnically segregated compared to Poso.

\section{Figure 6: CRISE perceptions survey: Perceived level of village segregation, by religion}

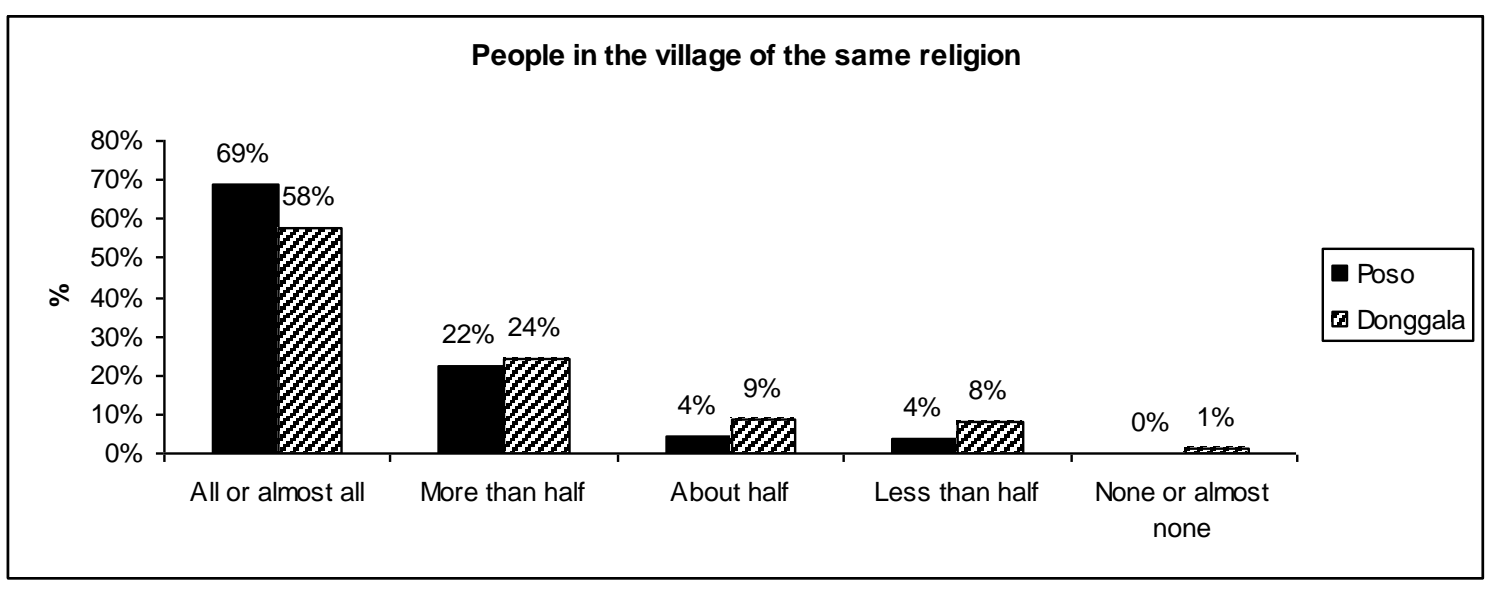

Notes: $\mathrm{N}=300 / \mathrm{District}$

Figure 7: CRISE perceptions survey: Perceived level of village segregation, by ethnicity

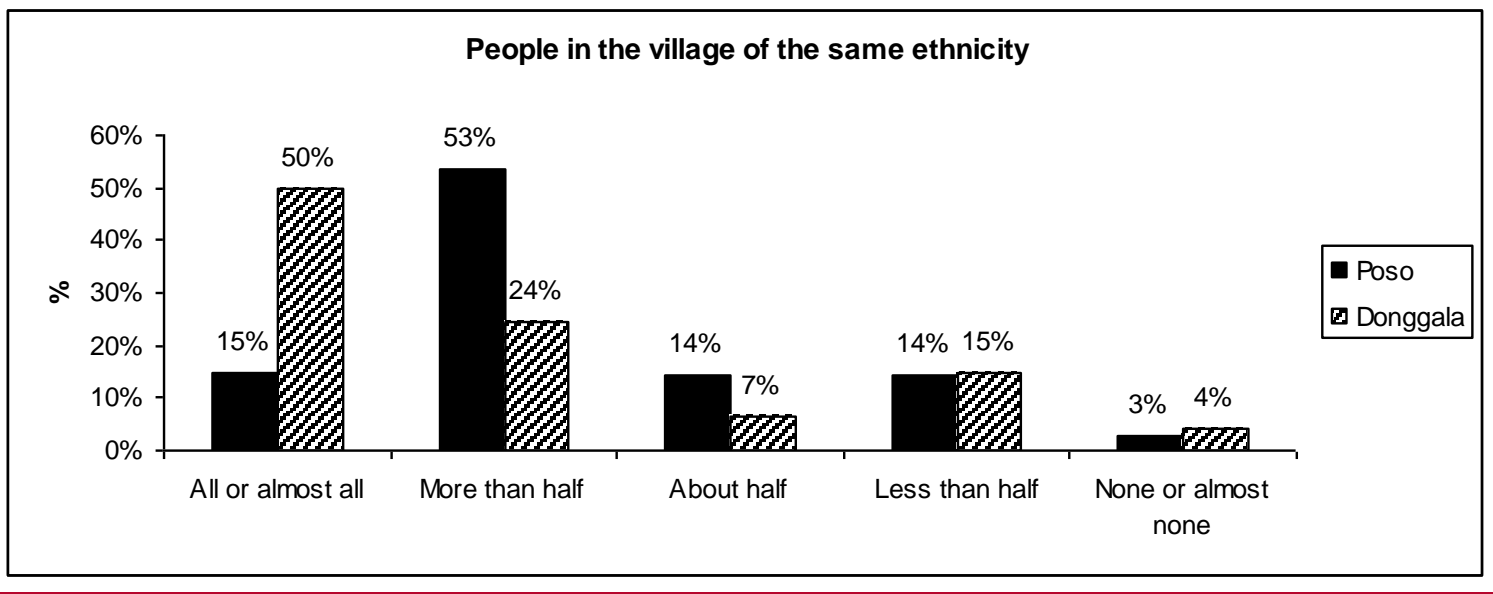

Notes: $\mathbf{N}=300 /$ District

While the district-splitting may have alleviated tensions and elite competition in Poso, it has potentially passed on the challenges of managing diversity to the new districts. For example, in Morowali, which now neighbours Poso, there is intense competition between elites over access to government positions and resources. The region is also rich in natural resources, including plantations and minerals, which provides considerable incentives for mobilisation and power-seeking. Bearing in mind that parts of Morowali were once involved in the Poso conflict, the local history of tensions between the predominantly Muslim Bungku kingdom and the predominantly Christian Mori kingdom 
provide a context in which there is potential for conflict in the future. Managing these tensions is required to ensure constructive rather than destructive competition takes place. Currently, the discourse in the district pertains to splitting the region again into the Mori and Bungku Districts, respectively.

One further consideration regarding the impact of decentralization on conflict dynamics in Poso is the scope the laws have provided for direct election of the District Head (Bupati) and how this intersects with local tensions. While the decentralization laws have allowed for direct elections in Indonesia, this new political space did not result in violence during the direct elections of the District Head in Poso in 2005. Brown and Diprose (2008) attribute most of this to the array of interventions put in place to ensure that the elections remained peaceful, in particular the deliberate inter-religious pairing of all candidates during the elections. Altogether, five slates of candidates stood for the District Head/Deputy District Head elections in Poso. Each pairing comprised a Muslim and a Christian; in three out of the five pairings, the Christian candidate was for the Bupati with a Muslim as his deputy; in the other two, vice versa.

Given the grievances over marginalisation discussed above, the history of violence and the emphasis the population placed on local security, as well as the fact that, following the implementation of decentralization and district-splitting, the population was $65 \%$ Christian, it is not surprising that a Christian whose mother was indigenous to the region, and a candidate who was backed by the Christian PDS party, won in a landslide. His popularity in the elections, despite the fact that he had spent most of his working years outside the province, was also reinforced by his background as a Police Chief, which many voters saw as an opportunity for ensuring better regional security at the height of the conflict. Interviews conducted pre and post-elections revealed that his party backing, background in the police, and available funding for the elections were responsible for his win over other 'local sons'. The results of the elections show the extent to which religious demographics played into the votes, which were backed by parties with strong religious links and accounted for the majority of the votes garnered (Brown and Diprose, 2009).

\section{Donggala: Decentralization and inequalities}

Decentralization has also had and is continuing to impact on demographics and tensions in Donggala. First, decentralization continues to impact on population dynamics and community relations through district splitting (pemekaran) in the region. Parigi Moutong was carved out of Donggala in 2003, as have a number of new sub-districts. During the interviews conducted in this research, discussions over plans to carve a new district out of Donggala - Kabupaten Sigi - were a source of heated debate in the district. The plan was endorsed by the then District Head. Driving through the sub-districts that would potentially fall within the bounds of Sigi saw banners and flags in all variety of local languages supporting the formation of the new district. Lobbying was in full swing in 2006 and 2007, with civil servant wages and electricity bills being levied to fund the district-splitting initiative despite some discontent with this fund raising decision. There were 12 sub-districts vying for a place in the new district in 2006: Sigi Biromaru, Dolo, South Dolo, Palolo, Kulawi, South Kulawi, Pipikoro, Gumbasa, Tanambulawa, Marawola and, albeit contested, Rio Pakawa and Pinembani. However, there was disagreement with the formation of the new district, particularly in border areas where they saw the risk of contentious politics in terms of mis-managed ethno-religious tensions. Thousands of people demonstrated in July 2007 against the formation of the 
new district, however, these concerns did not obstruct the eventual formation of Sigi district through Law No. 27, 2008 on July $21^{\text {st }}$. Seven sub-districts were split out of several of the sub-districts mentioned above, with five of these (West Dolo, Kinovaro, Lindu, West Marawola, and Nokilalaki) joining the new district, while Rio Pakawa and Pinembani were not included within the bounds of Sigi.

The demographics of the new district will roughly split the population between religions, and will increase the number of ethnicities seen as newcomers as a percentage of the population, thereby reducing the cross-cutting identities. Interviews in the region during the lobbying phase for the new district revealed that there was little reference and consideration in grassroots discourse about the impacts of such changes at all in terns of new social relations and tensions. Instead, support the formation of Sigi was based on increasing proximity to public services. Furthermore, several sources confirmed that elite competition for key positions in the new district had already begun in 2006, as had the formation of alliances between elites. Given the change in demographics, the competition for newly available executive positions, and the wealth of natural resources which fall within the boundaries of the new district, there are greater incentives to mobilise around some of the more sensitive identities which has rarely occurred in these sub-districts in the past.

Adding to these dynamics, the Donggala district head elections were held on 16 October 2008 following the death of District Head Adham Ardjad in November 2006. On the $28^{\text {th }}$ of October 2008, Golkar party candidates Habir Ponulele and Aly Lasamaulu were announced as the outright winners of the District Head and Deputy District Head positions with $35.5 \%$ of the vote (the next closest slate won $15.8 \%$ ), representing a continuation of the dominance of Golkar in the district. However, the elections were contentious, as voters in Sigi District were allowed to vote in the Donggala elections because they would continue to receive services from the Donggala government until the Sigi government would be ready in 2010 . While voting day was markedly peaceful, there was tense debate following the announcement of the results of the elections as other slates argued that votes from Sigi regions were what swayed the vote in favour of the Golkar slate. During the plenary session of the Donggala Elections Commission which ratified the winners, a brawl ensued in the meeting room between representatives of protesting groups and others supporting the announcement of the Golkar winners. Again, these incidents illustrate the fractious nature of local politics. Learning from the experience of Poso, it is important to anticipate the inevitable tensions of structural change in order to peacefully manage the ensuing transition period.

In some cases, sub-district splitting has heightened ethno-religious segregation. For example, in Kulawi sub-district there was once a large population of groups of 'newcomers' with ethnicities from all over the island, as well as a population of the indigenous Kulawi people. Now, the indigenous Kulawi predominantly occupy Kulawi sub-district, and the newcomers fall under the jurisdiction of South Kulawi. Some are concerned that this could result in inter-sub-district conflict resulting from these changes. However, of note are the efforts of traditional adat (customary) elders to solidify relations and interaction between these ethnicities through the formation of the inter-sub-district adat council which has had much success at mediating disputes from within and between villages, as well as encouraging interaction between the different sub-districts. One of the motivations to form the council was a series of meetings and appeals to the population not to get involved in the conflict in neighbouring Poso. This demonstrates that locals are 
identifying the potential tensions and problems that could result from decentralization, district-splitting and the consequent changes to population demographics, as well as changes in competition over access to power and resources. In response, interim institutions have been created (with some now becoming permanent institutions) to ensure that inter-group relations are promoted and problems are addressed as they arise.

Efforts on the part of leaders and the state to implement strategies which seek to desensitise sensitive identities and find bridging groupings outside of religion and ethnicity are important for reducing the likelihood of conflict. Furthermore, efforts to include minorities in government through either informal or more formal policies, as well as poverty alleviation strategies which address socio-economic horizontal inequalities are just some of the conflict management strategies which could be introduced to ensure that tensions don't escalate to the extent they did in Poso. Of course, demographics, history, public policy, and elite interests/incentives are not the only aspects to be considered when evaluating conflict dynamics. Mobilisation structures, grass roots grievances/interests, identity consciousness, national interventions, deliberate fostering or provocation of conflict and most importantly local conflict intervention mechanisms are all important elements for understanding sub-national patterns of conflict and violence. The discussion above looks at how the implementation of decentralization has intersected with some, not all of these elements. However, it does demonstrate that there have been some indirect impacts from decentralization on conflict dynamics in the region. An awareness of these dynamics is important for managing diversity and structural change in other regions in Indonesia.

\section{Conclusion}

Clearly the decentralization-conflict nexus should be situated in the ways in which decentralization ameliorates or exacerbates historic grievance of inter-group domination and horizontal inequalities, not just its impact on service delivery and growth which has been the case in other relevant literatures to the success of decentralization. This paper has examined how the history of grievances, demands, and identity politics in some decentralised units Indonesia have played out in the context of creation of new districts. Grievances towards centralised rule and horizontal inequalities have long existed in Indonesia, and form a historical backdrop to decentralization programmes, and thus should be considered when evaluating the impact of decentralization on conflict dynamics and centre-regional as well as intra-regional tensions.

While decentralization responds to longstanding grievances by providing opportunities for the expression of diversity and better attention to local needs, there are several key components of the implementation of decentralization have the potential to interact with identity politics and conflict dynamics in the regions. As the case studies demonstrate significant structural and institutional change will have ripple effects and can result in new tensions, which will be exacerbated if the process is poorly implemented. Decentralization indirectly interacts with conflict dynamics, particularly by stimulating changes in population demographics through sub-national splitting of administrative units; and, providing for local autonomy and local participation in decision making through direct elections; and creating incentives for local elites in both new and existing areas to compete for power and resources by mobilising sensitive identities. This is not to say that the demographic, structural, and institutional changes stimulated by the laws and demanded by the populace will necessarily lead to violent conflict, but rather that they do 
interact with or potentially stimulate local tensions. This can have positive and negative consequences, that is it can both ameliorate past tensions and grievances but also stimulate new ones.

The worst case scenario is when decentralization is implemented in ways that exacerbate perceptions of injustices and horizontal inequalities. This could either occur where historical minorities are further marginalised by the creation of new local governing units or where historically majorities are transformed into minorities through district splitting. Both situations tantamount to a travesty of decentralization to the extent that they fail to guarantee or extend the possibilities for local autonomy and self-governance. All told, it is the perverse manifestation and implementation of decentralization and not decentralization per se that triggers violent conflicts.

Effective interventions, awareness and forethought, and conflict management strategies which channel inter-group tensions into productive outcomes rather than destructive violence will ensure that diversity flourishes in multi-ethnic and religious states such as Indonesia. This will also ensure that what is a potentially a temporary phenomenon resulting from transition does not solidify into long-term grievances and potentially violent conflict.

\section{Bibliography}

Acciaioli, Greg (2001) 'Grounds of Conflict, Idioms of Harmony: Custom, Religion, and Nationalism in Violence Avoidance at the Lindu Plain, Central Sulawesi’, Indonesia, Vol. 72, October pp81-114

Ake, Claude (2000) The Feasibility of Democracy in Africa ,CODESRIA: Dakar

Aragon, Lorraine V. (2001) 'Communal Violence in Poso, Central Sulawesi: Where People Eat Fish and Fish Eat People’, Indonesia, Vol. 72, October, pp45-79

Aragon, Lorraine V. (2002) 'Waiting for Peace in Poso: Why Has This Muslim-Christian Conflict Continued for Three Years?’ Inside Indonesia, 70, April-June pp11-12

Bertrand, Jacques (2004) Nationalism and Ethnic Violence in Indonesia. Cambridge University Press: Cambridge

Bhakti, Ikrar Nusa, Heru Cahyono, M. Hamdan Basyar, Moch. Nurhasim, Riza Sihbudi and Sri Yanuarti (2001) Militer dan Politik Kekerasan Orde Baru, First Edition, LIPI, The Indonesian Institute of Sciences, Mizan: Bandung

BPS Poso (1998) Poso Dalam Angka, 1997, Badan Pusat Statistik Poso, Central Sulawesi

BPS Poso (2006) Poso Dalam Angka, 2005, Badan Pusat Statistik Poso, Central Sulawesi

BPS Sulawesi Tengah (2004) Sulawesi Tengah Dalam Angka, 2003, http://www.infokom-sulteng.go.id, accessed 16 March, 2005

Brancati, Dawn (2006) 'Decentralization: Fueling the Fire or dampening the Flames of Ethnic Conflict?' International Organization, Vol. 60, (Summer), pp. 651

Brown, Graham and Rachael Diprose (2009) 'Bare Chested Politics in Central Sulawesi: The Dynamics of Local Elections in a Post Conflict Region' in: Maribeth Erb, Priyambudi Sulistiyanto (eds), Pilkada: Indonesia's Local District Elections, (forthcoming) Asia Research Institute, National University of Singapore, pp, 352-373

Brubakar, Rogers (1996) Nationalism Reframed: nationhood and the National Question in New Europe, Cambridge University Press: New York

Cote, Joost (2005) "Historical roots of inter communal violence in Central Sulawesi", International Seminar: Religion and Conflict, Bandung 10-11January, 2005 
Diprose, Rachael (2008) Passing on the challenges or prescribing better management of diversity? Decentralization, power sharing, and conflict dynamics in Central Sulawesi. Conflict, Security and Development, 8(4): 393-425

Fanthorpe, Richard (2006) 'On the limits of liberal peace: Chiefs and democratic decentralization in postwar Sierra Leone', African Affairs, Vol. 105, No. 418, 27-49

Feith, Herbert (1962) The Decline of Constitutional Democracy in Indonesia, Cornell University Press: Ithaca

Foulcher, Keith (1990) 'The Construction of an Indonesian National Culture: Patterns of Hegemony and Resistance', in Arief Budiman (ed), State and Civil Society in Indonesia, Monash Papers on Southeast Asia, No. 22, Clayton pp. 301-320

Clifford Geertz. 1990. “"Popular Art" and the Javanese Tradition’, Indonesia, Vol.50, October: 77-94.

Guinness, Patrick (1994) 'Local Society and Culture', in Hal Hill (ed), Indonesia's New Order, Allen \& Unwin: St Leonards, pp.267-304

Gurr. T. R. (1970) Why men rebel. Princeton University Press: Princeton

Gurr, T. R. (1993). Minorities at Risk: A Global View of Ethnopolitical Conflicts. United States Institute of Peace Press: Washington, DC.

Gurr, T. R. (2000) People versus States: Minorities at Risk in the New Century, United States Institute of Peace Press: Washington D.C.

Gurr, T. R. (2001) Peace and Conflict 2001: A Global Survey of Armed Conflicts, Self-Determination Movements, and Democracy, Center for International Development and Conflict Management, University of Maryland: Maryland

Hardgrave, Robert Jnr. (1994) 'India: the Dilemmas of Diversity' in L. Diamond and M. F. Plattner (eds.) Nationalism, Ethnic Conflict and Democracy, John Hopkins University Press: Baltimore, pp. 71-85

Harvey, Barbara S. (1977), Permesta: Half a Rebellion, Cornell Modern Indonesia Project: Ithaca, Monograph Series No. 57

Hechter, Michael (2000) Containing Nationalism. Oxford University Press: Oxford and New York

Hefner, Robert W. (2000) Civil Islam. Muslims and democratization in Indonesia, Princeton University Press: Princeton

Hegre, Havard, Tanja Elingsen, Scott Gates, and Nils Petter Gleditsch (2001) "Towards a Democratic Civil Peace? Democracy, Political Change, and Civil War, 1816-1992.”, American Political Science Review 95(1): pp3-41

Hooker, Virginia Matheson (1995) 'New Order Language in Context' in Virginia Matheson Hooker (ed), Culture and Society in New Order Indonesia, Oxford University Press: Kuala Lumpur, pp272-289

Hooker, Virginia Matheson and Howard Dick (1995) 'Introduction', in Virginia Matheson Hooker (ed), Culture and Society in New Order Indonesia, Oxford University Press: Kuala Lumpur, pp1-25

Horowitz, Donald (1991) A Democratic South Africa? Constitutional Engineering in a Divided Society, University of California Press: Berkeley

Human Rights Watch (2002) Breakdown: Four Years of Communal Violence in Central Sulawesi. Human Rights Watch: New York

ICG (2005) Indonesia Backgrounder: Jihad in Central Sulawesi. International Crisis Group : Jakarta

Jackson, Paul (2007) 'Reshuffling an Old Deck of Cards? The Politics of Local Government Reform in Sierra Leone', African Affairs, Vol. 106, No. 422: 95-111

Kahin, Audrey R. and Kahin, George McT (1997) Subversi sebagai politik luar negeri:menyingkap keterlibatan CIA di Indonesia,Translator: Leirissa, R.Z, Pustaka Utama Grafiti, Jakarta (English: Subversion as Foreign Policy, The Secret Eisenhower and Dulles Debacle in Indonesia - 1995)

Kahin, George McTurnan (1969) Nationalism and Revolution in Indonesia, Cornell University Press: Ithaca

Klinken, Geert Arend van. (2007) Communal violence and democratization in Indonesia: small town wars, Routledge, London 
Kompas (2002, 12 August) 'Undang-Undang Dasar Negara Repubik Indonesia Tahun 1945 dan Perubahannya', p29-30

Kymlicka, Will (1998) 'Is Federalism and alternative to secession?' in Percy B. Lehning (ed.) Theories of Secession, Routledge Press: New York, pp111-150.

Legge, John (1961) Central Authority and Regional Autonomy in Indonesia: A Study in Local Administration, 1950-1960, Cornell University Press: Ithaca

Malley, Michael (1999) 'Regions: Centralization and Resistance', in Donald K. Emmerson (ed), Indonesia Beyond Suharto: Polity, Economy, Society, Transition, The Asia Society, M. E. Sharpe: Armonk, pp71-105

Mancini, Luca (2005) 'Horizontal Inequality and Communal Violence: Evidence from Indonesian Districts', CRISE Working Paper No.22, November, University of Oxford: Oxford

Ndegwa, Stephen (2002) 'Decentralization in Africa: A Stocktaking Survey', African Region Working Paper, No. 40, World Bank, Washington DC

Østby, Gudrun. (2008) 'Inequalities, the Political Environment and Civil Conflict: Evidence from 55 Developing Countries'. in Frances Stewart, ed. Horizontal Inequalities and Conflict: Understanding Group Violence in Multiethnic Societies, with a foreword by Kofi Annan, Palgrave: London

Rothchild, D. and P. Roeder (2001) Powersharing and Peacemaking, Carnegie Corporation

Said, Salim (2001) Militer Indonesia dan Politik, Dulu, Kini dan Kelak, (Indonesian Military and Politics, Past, Present, and Future) Sinar Harapan: Jakarta

Samego, Indria, Dewi Fortuna Anwar, Hamdan Basyar, Ikrar Nusa Bhakti, Maswadi Rauf, Riza Sihbudi and Sri Yanuarti (1998) “...Bila ABRI Menghendaki...," $2^{\text {nd }}$ Edition, LIPI, The Indonesian Institute of Sciences, Mizan : Bandung

Schrottshammer, E. and U. Kievelitz (2006) Decentralization: A Guideline, GTZ: Eschborn (Mimeo)

Sen, Krishna and Hill, David T. (2000) Media, Culture, and Politics in Indonesia, Oxford University Press: South Melbourne

Stewart, F. (2000) 'Crisis Prevention: Tackling Horizontal Inequalities', Oxford Development Studies, 28(3): 245-262

Stewart, F. (2002) "Horizontal Inequalities: A Neglected Dimension of Development”, QEH Working Paper Series No.81, Queen Elizabeth House, University of Oxford: Oxford

Stewart, F., G. Brown, and L. Mancini (2005) "Why Horizontal Inequalities Matter: Some Implications for Measurement”, CRISE Working Paper No. 19, Queen Elizabeth House, University of Oxford: Oxford

Stewart, F (ed.) (2008) Horizontal Inequalities and Conflict: Understanding Group Violence in Multiethnic Societies, with a foreword by Kofi Annan, Palgrave: London

Suberu, Rotimi. (1994) 'The travails of federalism in Nigeria' in L. Diamond and M. F. Plattner (eds.) Nationalism, Ethnic Conflict and Democracy, John Hopkins University Press: Baltimore, pp. 56-70.

Suberu, Rotimi T. (2006) 'Federal Dilemma in Africa: The Nigerian Experience in Comparative Perspective, conference paper presented at the CRISE Conference on Federalism, Decentralization, and Conflict, University of Oxford: October 2006

Snyder, Jack (2000) From Voting to Violence: democratization and Ethnic Conflict, W.W. Norton: New York

Tirtosudarmo, Riwanto (2006) 'Eastern Sulawesi Province? Decentralization policy and the politics of transcending boundaries in Eastern Indonesia', conference paper presented at the CRISE Conference on Federalism, Decentralization, and Conflict, University of Oxford: October 2006

Usman, Syaikhu (2001) 'Indonesia's Decentralization Policy: Initial Experiences and Emerging Problems', Third EUROSEAS Conference on Decentralization and Democratization, London, pp1-28

Varshney, Ashutosh, Rizal Panggabean, and Mohammad Zulfan Tadjoeddin (2004) Patterns of Collective Violence in Indonesia (1990-2003), Jakarta: UNSFIR Working Paper 04/03

YAPPIKA (2003) Suara dari Poso: Kerusuhan, konflik, dan resolusi. YAPPIKA: Jakarta 